\title{
Impact of dietary Chlorella vulgaris and carbohydrate-active enzymes incorporation on plasma metabolites and liver lipid composition of broilers
}

Diogo Francisco Maurício Coelho ${ }^{1 \dagger}$, Cristina Maria Riscado Pereira Mateus Alfaia ${ }^{1 \dagger}$, José Miguel Pestana Assunção ${ }^{1}$, Mónica Costa', Rui Manuel Amaro Pinto ${ }^{2}$, Carlos Mendes Godinho de Andrade Fontes ${ }^{1}$, Madalena M. Lordelo ${ }^{3}$ and José António Mestre Prates ${ }^{1 *}$

\begin{abstract}
Background: Chlorella vulgaris has been proposed as a sustainable green feedstock in poultry nutrition due to its ease of cultivation, minimal environmental impact and balanced nutritional composition. However, the majority of studies documents the use of $C$. vulgaris as a dietary supplement in broilers instead of a feed ingredient. To the best of our knowledge, no report has shown the effect of a high-level incorporation ( $>2 \%$ in the diet) of $C$. vulgaris on plasma metabolites and hepatic lipid composition of broilers. One hundred and twenty Ross 308 male birds were housed in 40 wired-floor cages and randomly distributed by the following experimental diets at 22 days of age $(n=10)$ during 15 days: (1) a corn-soybean meal based diet (control); (2) based diet with $10 \%$ of $C$. vulgaris; (3) diet 2 supplemented with $0.005 \%$ Rovabio ${ }^{\circ}$ Excel AP; and (4) diet 2 supplemented with $0.01 \%$ of a pre-selected four-CAZyme mixture.

Results: The inclusion of C. vulgaris at 10\% in the diet, regardless of the presence of exogenous CAZymes, changed plasma metabolites but did not compromise broilers growth. Plasma total lipids increased in broilers fed $C$. vulgaris combined with the two feed CAZymes $(p<0.001)$ compared with the control diet. Moreover, the supplementation with Rovabio increased total cholesterol and LDL-cholesterol, while the addition of the four-CAZyme mixture increased triacylglycerols, VLDL-cholesterol and ALP activity. In opposition, HDL-cholesterol levels decreased in broilers fed microalga alone $(p=0.002)$. Regarding hepatic composition, the inclusion of $C$. vulgaris in broiler diets, individually or combined with exogenous CAZymes, had a minor effect on fatty acids but improved the $n-6 / n-3$ ratio and total carotenoids.
\end{abstract}

\footnotetext{
* Correspondence: japrates@fmv.utl.pt

${ }^{\dagger}$ Diogo Francisco Maurício Coelho and Cristina Maria Riscado Pereira Mateus

Alfaia contributed equally to this work.

${ }^{1}$ CIISA - Centro de Investigação Interdisciplinar em Sanidade Animal,

Faculdade de Medicina Veterinária, Universidade de Lisboa, 1300-477 Lisboa, Portugal

Full list of author information is available at the end of the article
}

(c) The Author(s). 2021 Open Access This article is licensed under a Creative Commons Attribution 4.0 International License, which permits use, sharing, adaptation, distribution and reproduction in any medium or format, as long as you give appropriate credit to the original author(s) and the source, provide a link to the Creative Commons licence, and indicate if changes were made. The images or other third party material in this article are included in the article's Creative Commons licence, unless indicated otherwise in a credit line to the material. If material is not included in the article's Creative Commons licence and your intended use is not permitted by statutory regulation or exceeds the permitted use, you will need to obtain permission directly from the copyright holder. To view a copy of this licence, visit http://creativecommons.org/licenses/by/4.0/. The Creative Commons Public Domain Dedication waiver (http://creativecommons.org/publicdomain/zero/1.0/) applies to the data made available in this article, unless otherwise stated in a credit line to the data. 
Conclusions: In summary, the inclusion of a high level (10\%) of C. vulgaris in broiler's diet, regardless of the presence of exogenous CAZymes, improved hepatic antioxidant composition and did not impair broiler's performance. In addition, the feed supplementation with CAZymes increased broilers lipemia. Therefore, dietary C. vulgaris at this incorporation level seems to be safe for animal health and do not compromise performance traits, with no need of CAZymes supplementation.

Keywords: Chlorella vulgaris, CAZymes, plasma metabolites, liver composition, broiler

\section{Background}

Broiler meat is one of the most consumed meats worldwide, thus being a major source of animal protein for human consumption [1]. The increasing demand of broiler meat has brought new challenges to livestock agriculture. In addition, the increase of broiler production led to an intensive production of conventional feed raw materials, mainly corn and soybean, which has a negative impact on environmental sustainability. Moreover, health-conscious consumers are driving the demand for products with a high nutritional value $[2,3]$.

The use of microalgae as animal feed, mainly in poultry, has been considered a sustainable and promising alternative to face the challenge imposed on livestock agriculture. Microalgae production does not require arable land or potable water, thus not competing with human food. Additionally, through the photosynthetic process, microalgae could help mitigate the increase of atmospheric carbon dioxide [4]. Moreover, microalgae display an interesting nutritional composition, with a balanced protein concentration and amino acid profile, which is comparable or superior to the conventional protein sources used in animal feeding. Microalgae also present interesting contents of $n-3$ and $n-6$ polyunsaturated fatty acids (PUFA), including eicosapentaenoic acid (EPA) and docosahexaenoic acid (DHA), carbohydrates, vitamins, minerals, carotenoids and antioxidants $[5,6]$. Chlorella vulgaris, a freshwater eukaryotic green microalga, stands out for its relative ease of cultivation, high yield of biomass production and a well-balanced nutritional composition, being one of the most produced microalgae worldwide $[7,8]$. However, C. vulgaris contains a recalcitrant cell wall, composed by a diverse and complex matrix of cross-linked insoluble carbohydrates, which are largely indigestible by monogastrics [9-11]. Carbohydrate-Active enZymes (CAZymes) have been applied in monogastric livestock as feed additives [12, 13]. Beyond its recognized ability to degrade cereal cell walls [14], CAZymes also demonstrated the capacity to disrupt microalgae cell walls $[15,16]$. Recently, a recombinant four-CAZyme mixture, was developed in vitro to partially degrade the $C$. vulgaris, enabling the release of trapped nutrients [17]. Furthermore, C. vulgaris has been regarded as dietary supplement in human and animal studies due to its antioxidant, antidiabetic, antihyperlipidemic, immunomodulatory and anti-inflammatory properties $[18,19]$. Thus, the incorporation of C. vulgaris not only improves the nutritional value of diets, and consequently growth performance, but also enhances animal health [20]. However, until to date, the majority of these studies have been carried out with the incorporation of $C$. vulgaris at low levels ( $<2 \%$ in diet). Hereupon, this study was conducted to assess the effect of dietary C. vulgaris incorporation at $10 \%$, supplemented or not with the commercially available Rovabio and the four-CAZyme mixture described by Coelho et al. [17], on plasma metabolites and hepatic lipid composition of broilers.

\section{Results}

Feed Intake and growth performance of broilers

Table 1 displays the results on feed intake and growth performance of broilers for contextualization purposes. The experimental diets had no significant effect neither on feed intake nor on growth performance $(p>0.05)$. Values of average daily feed intake (ADFI), average daily gain (ADG) and feed conversion ratio (FCR) were $127 \mathrm{~g}$, 80.5 and $1.56 \mathrm{~g}$, respectively.

\section{Plasma biochemical profile}

Plasma metabolites of broilers fed $10 \%$ of C. vulgaris, individually or combined with exogenous CAZymes, are presented in Table 2 . Total lipids were significantly increased $(p<0.001)$ in broilers fed with CHR and CHM diets when compared with the ones fed $\mathrm{CH}$ and control diets. Broilers fed CHR had higher total cholesterol $(p<$ $0.001)$ and low-density lipoprotein cholesterol (LDL) $(p<0.001)$ relative to the other diets. CHM had higher triacylglycerols (TAG) $(p<0.001)$ and very-low-density lipoprotein cholesterol (VLDL) $(p<0.001)$ when compared to $\mathrm{CH}$ and control diets. On the contrary, $\mathrm{CH}$ diet decreased high-density lipoprotein cholesterol (HDL) levels $(p=0.002)$. These alterations resulted in a lower total cholesterol/HDL-cholesterol ratio $(p<0.001)$, simultaneously with lower total protein, in the control diet compared to the other diets. In addition, broilers fed 
Table 1 Effect of experimental diets on growth performance parameters of broilers

\begin{tabular}{lcccccc}
\hline Item & Control & CH & CHR & CHM & SEM & \multicolumn{1}{c}{-value } \\
\hline Initial weight, g & 786.8 & 788.3 & 780.2 & 783.4 & 12.67 & 0.969 \\
Final weight, g & 1867.4 & 1927.8 & 1923.2 & 1929.2 & 52.89 & 0.811 \\
ADG, g/d & 77.2 & 81.4 & 81.6 & 124.8 & 2.406 & 0.991 \\
ADFl, g/pen & 128.4 & 124.0 & 1.528 & 1.602 & 3.644 & 0.037 \\
FCR & 1.590 & 1.537 & 0.464
\end{tabular}

The broilers were fed: (1) a corn-soybean based diet (Control); (2) the based diet plus $10 \%$ C. vulgaris (CH); (3) diet 2 supplemented with $0.005 \%$ Rovabio Excel AP; and (4) diet 2 supplemented with $0.01 \%$ of a pre-selected four-CAZyme mixture (CHM)

SEM - standard error of the mean; ADFI - average daily feed intake; ADG - average daily weight gain; FCR - feed conversion ratio

CHM diet decreased glucose $(p=0.001)$ when compared to the control diet. Although creatinine levels remained unchanged among experimental diets $(\mathrm{p}>0.05)$, urea increased $(p<0.001)$ in broilers fed C. vulgaris alone.

Regarding liver enzymes, alanine aminotransferase (ALT) and aspartate aminotransferase (AST) activities in plasma were unaffected $(p>0.05)$ by the experimental diets. Curiously, CHM diet increased plasma alkaline phosphatase (ALP) $(p<0.001)$ but decreased gammaglutamyltransferase $(\mathrm{GGT})(p<0.001)$, when compared to the other diets.

\section{Hepatic total lipids, total cholesterol and fatty acid composition}

The effect of $C$. vulgaris, individually or in combination with feed enzymes, on hepatic total lipids, cholesterol content and fatty acid composition of broilers is shown in Table 3. Experimental diets did not contribute to significant differences on total lipids and total cholesterol contents $(p>0.05)$. The predominant fatty acids found in liver were C18:0 (22.9-24.4\%), C18:2n-6 (20.0$20.6 \%), \mathrm{C} 16: 0$ (17.6-19.6\%), C20:4n-6 (11.5-13.1\%) and C18:1c9 (10.1-12.9\% of total FAME). However, only 3

Table 2 Effect of experimental diets on plasma metabolites of broilers

\begin{tabular}{|c|c|c|c|c|c|c|}
\hline Item & Control & $\mathrm{CH}$ & CHR & $\mathrm{CHM}$ & SEM & $p$-value \\
\hline \multicolumn{7}{|l|}{ Plasma metabolites } \\
\hline Total lipids $(\mathrm{mg} / \mathrm{L})^{1}$ & $3578^{\mathrm{a}}$ & $3500^{a}$ & $3941^{b}$ & $3932^{b}$ & 60.26 & $<0.001$ \\
\hline TAG (mg/L) & $358^{\mathrm{a}}$ & $402^{\mathrm{b}}$ & $475^{\mathrm{bc}}$ & $526^{\mathrm{C}}$ & 23.68 & $<0.001$ \\
\hline Total cholesterol (mg/L) & $860^{a}$ & $799^{a}$ & $983^{c}$ & $953^{b}$ & 23.36 & $<0.001$ \\
\hline HDL-cholesterol (mg/L) & $641^{\mathrm{b}}$ & $566^{a}$ & $641^{\mathrm{b}}$ & $672^{\mathrm{b}}$ & 18.78 & 0.002 \\
\hline LDL-cholesterol (mg/L) & $125^{\mathrm{a}}$ & $150^{b}$ & $240^{d}$ & $178^{c}$ & 4.63 & $<0.001$ \\
\hline VLDL-cholesterol $(\mathrm{mg} / \mathrm{L})^{2}$ & $71.6^{\mathrm{a}}$ & $80.4^{\mathrm{ab}}$ & $95.0^{\mathrm{bc}}$ & $105^{c}$ & 4.73 & $<0.001$ \\
\hline Total cholesterol/HDL-C & $1.34^{\mathrm{a}}$ & $1.41^{\mathrm{b}}$ & $1.54^{\mathrm{c}}$ & $1.42^{\mathrm{b}}$ & 0.017 & $<0.001$ \\
\hline Glucose (mg/L) & $2571^{b}$ & $2463^{\mathrm{ab}}$ & $2452^{\mathrm{ab}}$ & $2357^{a}$ & 33.78 & 0.001 \\
\hline Urea (mg/L) & $10.80^{\mathrm{ab}}$ & $15.80^{c}$ & $13.70^{b c}$ & $9.60^{\mathrm{a}}$ & 0.83 & $<0.001$ \\
\hline Creatinine (mg/L) & 0.15 & 0.13 & 0.09 & 0.16 & 0.02 & 0.160 \\
\hline Total protein (g/L) & $25.87^{\mathrm{a}}$ & $28.93^{b}$ & $28.97^{b}$ & $28.85^{b}$ & 0.68 & 0.005 \\
\hline \multicolumn{7}{|l|}{ Plasma hepatic markers } \\
\hline $\mathrm{ALT}(\mathrm{U} / \mathrm{L})$ & 3.70 & 4.60 & 5.50 & 5.30 & 0.589 & 0.146 \\
\hline AST (U/L) & 235.7 & 297.2 & 314.0 & 241.4 & 23.7 & 0.056 \\
\hline $\mathrm{ALP}(\mathrm{U} / \mathrm{L})$ & $3552^{b}$ & $2820^{\mathrm{ab}}$ & $2149^{a}$ & $5040^{c}$ & 198.6 & $<0.001$ \\
\hline GGT (U/L) & $21.2^{b}$ & $19.4^{b}$ & $20.5^{\mathrm{b}}$ & $15.3^{\mathrm{a}}$ & 0.920 & $<0.001$ \\
\hline
\end{tabular}

The broilers were fed: (1) a corn-soybean based diet (Control); (2) the based diet plus 10\% C. vulgaris (CH); (3) diet 2 supplemented with $0.005 \%$ Rovabio Excel AP; and (4) diet 2 supplemented with $0.01 \%$ of a pre-selected four-CAZyme mixture (CHM)

SEM - standard error of the mean; TAG - triacylglycerols; HDL - high-density lipoproteins; LDL - low-density lipoproteins; VLDL - very low-density lipoproteins; ALT alanine aminotransferase (EC 2.6.1.2); AST - aspartate aminotransferase (E.C. 2.6.1.1); ALP - alkaline phosphatase (EC 3.1.3.1); GGT - gamma-glutamyltransferase (EC 2.3.2.13)

${ }^{1}$ Total lipids $=$ [total cholesterol $] \times 1.12+[$ TAG] $\times 1.33+148$, as described by Covaci et al. [21]

${ }^{2}$ VLDL-cholesterol $=1 / 5$ [TAG], as described by Friedewald et al. [22]

a.b,c Different superscripts within a row indicate a significant difference $(p<0.05)$ 
Table 3 Effect of experimental diets on hepatic total lipids, total cholesterol and fatty acid (FA) composition of broilers

\begin{tabular}{|c|c|c|c|c|c|c|}
\hline Item & Control & $\mathrm{CH}$ & CHR & CHM & SEM & $p$-value \\
\hline Total lipids, $\mathrm{g} / 100 \mathrm{~g}$ & 3.10 & 2.90 & 3.20 & 2.98 & 0.126 & 0.363 \\
\hline Total cholesterol, $\mathrm{mg} / \mathrm{g}$ & 1.09 & 1.17 & 1.18 & 1.06 & 0.073 & 0.614 \\
\hline \multicolumn{7}{|c|}{ FA composition, $g / 100 \mathrm{~g} F A$} \\
\hline C10:0 & 0.01 & 0.00 & 0.01 & 0.00 & 0.002 & 0.192 \\
\hline C12:0 & 0.01 & 0.01 & 0.01 & 0.01 & 0.003 & 0.446 \\
\hline C14:0 & 0.22 & 0.17 & 0.22 & 0.20 & 0.025 & 0.395 \\
\hline C14:1C9 & 0.02 & 0.01 & 0.01 & 0.01 & 0.005 & 0.851 \\
\hline C15:0 & 0.05 & 0.05 & 0.05 & 0.05 & 0.005 & 0.988 \\
\hline DMA-C16:0 & 0.11 & 0.13 & 0.13 & 0.11 & 0.018 & 0.819 \\
\hline C16:0 & 19.6 & 17.6 & 18.6 & 18.6 & 0.920 & 0.533 \\
\hline C16:1C7 & $0.18^{\mathrm{a}}$ & $0.28^{b}$ & $0.27^{b}$ & $0.30^{\mathrm{b}}$ & 0.014 & $<0.001$ \\
\hline C16:1C9 & 0.69 & 0.46 & 0.48 & 0.62 & 0.135 & 0.580 \\
\hline C17:0 & 0.34 & 0.41 & 0.41 & 0.40 & 0.028 & 0.210 \\
\hline C17:1C9 & 0.03 & 0.04 & 0.04 & 0.04 & 0.005 & 0.108 \\
\hline DMA-C18:0 & 0.18 & 0.26 & 0.26 & 0.21 & 0.037 & 0.369 \\
\hline DMA-C18:1 & 0.02 & 0.01 & 0.02 & 0.02 & 0.004 & 0.848 \\
\hline C18:0 & 22.9 & 24.4 & 24.3 & 23.6 & 0.540 & 0.222 \\
\hline C18:1C9 & 12.9 & 10.1 & 10.5 & 12.2 & 1.628 & 0.562 \\
\hline C18:1c11 & 1.11 & 1.26 & 1.22 & 1.28 & 0.044 & 0.048 \\
\hline$C 18: 2 n-6$ & 20.0 & 20.5 & 20.6 & 20.0 & 0.603 & 0.860 \\
\hline C18:3n-6 & 0.03 & 0.04 & 0.04 & 0.04 & 0.003 & 0.255 \\
\hline C18:2t9t12 & 0.14 & 0.14 & 0.13 & 0.15 & 0.011 & 0.794 \\
\hline C18:3n-3 & 0.46 & 0.56 & 0.57 & 0.58 & 0.035 & 0.099 \\
\hline C18:4n-3 & 0.01 & 0.02 & 0.02 & 0.02 & 0.002 & 0.100 \\
\hline C20:0 & 0.14 & 0.15 & 0.14 & 0.14 & 0.009 & 0.806 \\
\hline C20:1C11 & 0.29 & 0.24 & 0.24 & 0.25 & 0.021 & 0.282 \\
\hline$C 20: 2 n-6$ & 1.09 & 1.21 & 1.13 & 1.04 & 0.085 & 0.564 \\
\hline$C 20: 3 n-6$ & 1.13 & 1.04 & 1.03 & 1.11 & 0.095 & 0.843 \\
\hline$C 20: 4 n-6$ & 11.7 & 13.1 & 12.1 & 11.5 & 1.034 & 0.695 \\
\hline$C 20: 3 n-3$ & $0.08^{\mathrm{a}}$ & $0.12^{b}$ & $0.12^{b}$ & $0.11^{\mathrm{ab}}$ & 0.009 & 0.032 \\
\hline$C 20: 5 n-3$ & 0.22 & 0.28 & 0.30 & 0.29 & 0.022 & 0.065 \\
\hline C22:0 & 0.07 & 0.07 & 0.07 & 0.07 & 0.005 & 0.973 \\
\hline$C 22: 1 n-9$ & 0.01 & 0.01 & 0.01 & 0.01 & 0.002 & 0.589 \\
\hline$C 22: 2 n-6$ & 0.015 & 0.012 & 0.016 & 0.012 & 0.002 & 0.316 \\
\hline$C 22: 5 n-3$ & 1.24 & 1.18 & 1.07 & 1.02 & 0.111 & 0.481 \\
\hline$C 22: 6 n-3$ & 1.95 & 3.02 & 2.79 & 2.63 & 0.324 & 0.130 \\
\hline Others & 3.56 & 2.82 & 3.35 & 2.98 & 0.343 & 0.426 \\
\hline \multicolumn{7}{|c|}{ Partial sums of $F A, g / 100 \mathrm{~g} F A$} \\
\hline $\mathrm{SFA}^{1}$ & 43.3 & 42.8 & 43.8 & 43.1 & 0.568 & 0.659 \\
\hline MUFA $^{2}$ & 15.2 & 12.4 & 12.8 & 14.8 & 1.785 & 0.601 \\
\hline PUFA $^{3}$ & 38.1 & 41.2 & 39.9 & 38.5 & 1.932 & 0.667 \\
\hline$n-6$ PUFA $^{4}$ & 34.0 & 35.9 & 34.9 & 33.7 & 1.594 & 0.773 \\
\hline$n-3$ PUFA $^{5}$ & 3.97 & 5.18 & 4.87 & 4.64 & 0.396 & 0.191 \\
\hline
\end{tabular}


Table 3 Effect of experimental diets on hepatic total lipids, total cholesterol and fatty acid (FA) composition of broilers (Continued)

\begin{tabular}{|c|c|c|c|c|c|c|}
\hline Item & Control & $\mathrm{CH}$ & CHR & CHM & SEM & $p$-value \\
\hline \multicolumn{7}{|c|}{ Ratios of FA } \\
\hline PUFA/SFA & 0.88 & 0.97 & 0.92 & 0.90 & 0.053 & 0.672 \\
\hline$n-6 / n-3$ & $8.79^{\mathrm{a}}$ & $7.22^{\mathrm{b}}$ & $7.38^{\mathrm{ab}}$ & $7.57^{\mathrm{ab}}$ & 0.382 & 0.025 \\
\hline $\begin{array}{l}\text { The broilers } \\
\text { AP; and (4) } \\
\text { SEM - stand } \\
\text { fatty acids } \\
{ }^{1} \text { Sum (C10: } \\
{ }^{2} \text { Sum (C14: } \\
{ }^{3} \text { Sum (C18: } \\
{ }^{4} \text { Sum (C18: } \\
{ }^{5} \text { Sum (C18: }\end{array}$ & $\begin{array}{l}\text { based diet } \\
1 \% \text { of a pr } \\
\text { tty acids; } \\
\\
\text { C17:0, C18:C } \\
\text {, C17:1 } 10 \\
8: 3 n-3, \text { C18 } \\
: 3 n-6, C 20: 4 \\
5 n-3, C 22: 5\end{array}$ & $\begin{array}{l}\text { the bas } \\
\text { r-CAZyn } \\
\text { lacetal; } \\
\text { ) } \\
\text { : } 1 \text { c11, C } \\
-620: 3\end{array}$ & $\begin{array}{l}0 \% \text { C. vu } \\
\text { HM) } \\
\text { d fatty a } \\
n-9) \\
\text { C20:3n-3 }\end{array}$ & $\begin{array}{l}\text { diet } 2 s \\
\text { monouns } \\
22: 5 n-3,\end{array}$ & $\begin{array}{l}\text { vith } 0.0 \\
\text { acids; }\end{array}$ & $\begin{array}{l}\text { Excel } \\
\text { saturated }\end{array}$ \\
\hline
\end{tabular}

minor fatty acids out of the 33 fatty acids identified were affected by the experimental diets. The proportion of C16:1c7 $(p<0.001)$ was higher in broilers fed microalga, with and without CAZymes, compared to those fed the control diet. Similarly, the proportion of C20:3n-3 was significantly lower in the control diet relative to $\mathrm{CH}$ ( $p=$ 0.032). Moreover, the experimental diets did not change the partial sums of fatty acids and the PUFA/SFA ratio $(p>0.05)$, but a significant decrease of $n-6 / n-3$ ratio was observed in all microalga diets compared to the control $\operatorname{diet}(p=0.025)$.

\section{Hepatic tocopherols and pigments}

Hepatic vitamin E homologues and pigments of broilers fed $C$. vulgaris, individually or combined with exogenous CAZymes, are presented in Table 4. Although $\alpha$-tocopherol was unchanged by the experimental diets, $\gamma$-tocopherol was consistently decreased in broilers fed $C$. vulgaris, regardless the presence of CAZymes $(p<0.001)$. In contrast, $\beta$-carotene increased with $\mathrm{CH}$ and $\mathrm{CHR}$ diets compared to the control diet $(p<0.001)$. Chlorophyll- $a$ increased with $\mathrm{CHM}$ relative to the control and $\mathrm{CH}$ diets $(p=0.011)$. In addition, broilers fed microalga diets had higher total carotenoids and total chlorophylls plus carotenoids than broilers fed the control diet $(p<0.001)$.

\section{Principal component analysis}

Principal component analysis (PCA) was performed to evaluate the relationship of plasma metabolites and hepatic lipid composition of broilers fed the four experimental diets. Hepatic parameters had no relationship (see Supplementary Fig. 1) using this discriminant analysis. Hence, Fig. 1 A shows only the PCA of plasma metabolites to describe the variability of the pooled data into two dimensions. The first two discriminant factors

Table 4 Effect of experimental diets on a-tocopherol, $y$-tocopherol and pigments of liver from broilers

\begin{tabular}{|c|c|c|c|c|c|c|}
\hline Item & Control & $\mathrm{CH}$ & CHR & CHM & SEM & $p$-value \\
\hline \multicolumn{7}{|l|}{ Diterpene profile, $\mu \mathrm{g} / \mathrm{g}$} \\
\hline a-Tocopherol & 6.66 & 6.07 & 5.43 & 4.91 & 0.626 & 0.199 \\
\hline y-Tocopherol & $1.26^{\mathrm{b}}$ & $0.822^{\mathrm{a}}$ & $0.833^{\mathrm{a}}$ & $0.840^{\mathrm{a}}$ & 0.070 & $<0.0001$ \\
\hline \multicolumn{7}{|l|}{ Pigments, $\mu g / g$} \\
\hline$\beta$-Carotene & $0.977^{a}$ & $3.66^{\mathrm{c}}$ & $3.15^{b c}$ & $2.11^{\mathrm{ab}}$ & 0.388 & $<0.0001$ \\
\hline Chlorophyll- $a^{1}$ & $2.44^{\mathrm{a}}$ & $2.12^{\mathrm{a}}$ & $3.66^{\mathrm{ab}}$ & $4.21^{\mathrm{b}}$ & 0.477 & 0.011 \\
\hline Chlorophyll- $b^{2}$ & 4.94 & 3.36 & 6.12 & 5.68 & 0.897 & 0.161 \\
\hline Total chlorophylls ${ }^{3}$ & 7.33 & 5.49 & 9.78 & 9.67 & 1.38 & 0.102 \\
\hline Total carotenoids ${ }^{4}$ & $2.14^{\mathrm{a}}$ & $10.1^{\mathrm{b}}$ & $10.5^{b}$ & $8.49^{b}$ & 0.860 & $<0.001$ \\
\hline Total chlorophylls + Carotenoids ${ }^{5}$ & $9.48^{\mathrm{a}}$ & $15.7^{\mathrm{b}}$ & $20.2^{b}$ & $18.2^{b}$ & 1.65 & $<0.001$ \\
\hline
\end{tabular}

The broilers were fed: (1) a corn-soybean based diet (Control); (2) the based diet plus $10 \%$ C. vulgaris (CH); (3) diet 2 supplemented with $0.005 \%$ Rovabio ${ }^{\oplus}$ Excel AP; and (4) diet 2 supplemented with $0.01 \%$ of a pre-selected four-CAZyme mixture (CHM)

SEM - standard error of the mean

${ }^{1} \mathrm{Ca}=11.24 \times \mathrm{A}_{662}-2.04 \times \mathrm{A}_{645}$

${ }^{2} \mathrm{Cb}=0.13 \times \mathrm{A}_{645}-4.19 \times \mathrm{A}_{662}$

${ }^{3} \mathrm{Ca}+\mathrm{b}=7.05 \times \mathrm{A}_{662}+18.09 \times \mathrm{A}_{645}$

${ }^{4} \mathrm{Cx}+\mathrm{C}=\left(1000 \times \mathrm{A}_{470}-1.90 \times \mathrm{Ca}-63.14 \times \mathrm{Cb}\right) / 214$

$5(\mathrm{Ca}+\mathrm{b})+(\mathrm{Cx}+\mathrm{c})$

$a, b, c$ Mean values within a row with unlike superscript letters are significantly different $(p<0.05)$ 

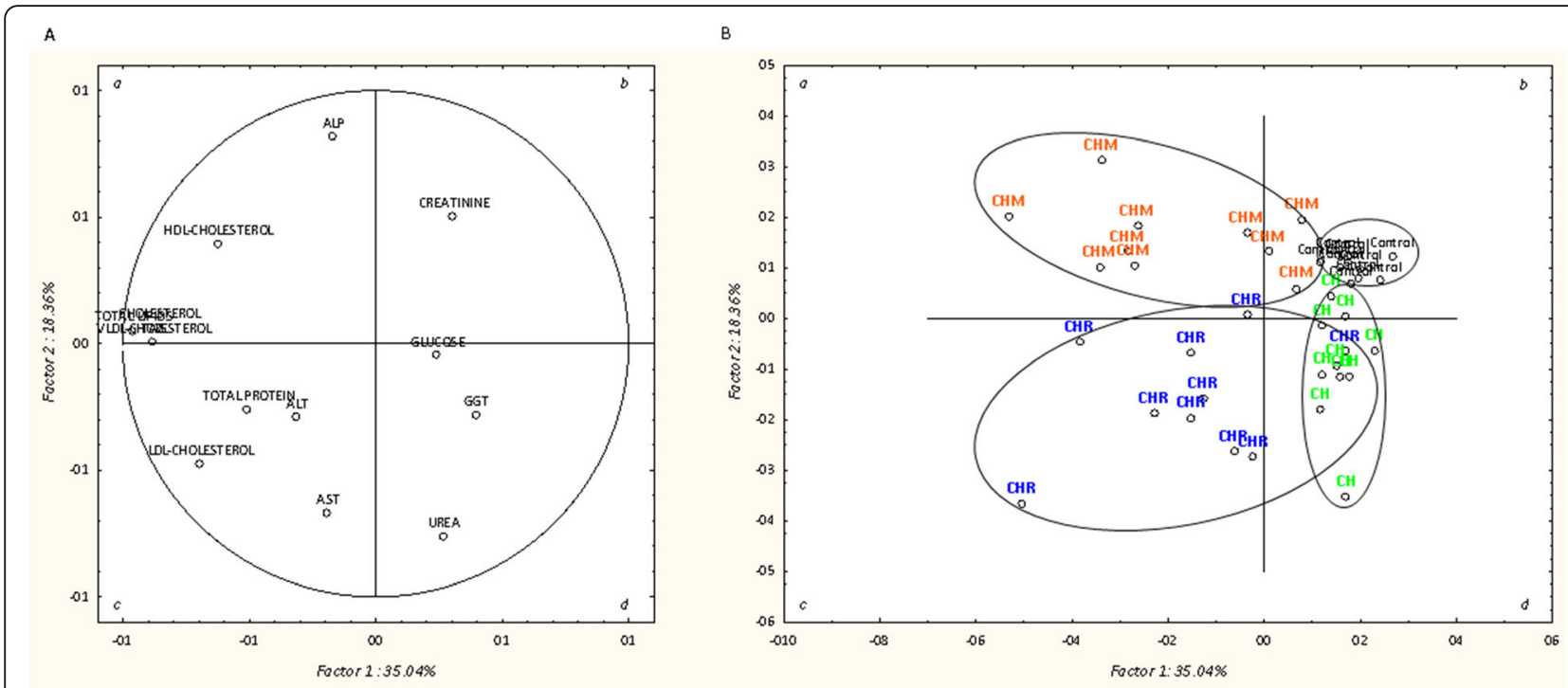

Fig. 1 Loading plot of the first and second principal components of the pooled data (A) and component score vectors (B) using plasma metabolites from broilers fed Chlorella vulgaris, individually and combined with exogenous CAZymes. Dietary treatments: corn-soybean meal based diet (control); based diet with $10 \%$ of C. vulgaris (CH); based diet with $10 \%$ of C. vulgaris supplemented with $0.005 \%$ Rovabio Excel AP (CHR); based diet with $10 \%$ of C. vulgaris supplemented with $0.01 \%$ of a pre-selected four-CAZyme mixture (CHM)

explained about $53.4 \%$ of total variability, with $35.0 \%$ for factor 1 and $18.4 \%$ for factor 2 . The loadings for the first two factors obtained for each variable are presented in Table 5. Plasma metabolites with the highest discriminant power were total lipids, TAG, VLDL-cholesterol and total cholesterol, on the factor 1, and ALP, urea and AST, on the factor 2. The PCA model revealed a good separation of the experimental groups, which are located

Table 5 Loadings for the first two principal components

\begin{tabular}{lcc}
\hline Variables & Factor $\mathbf{1}$ & Factor $\mathbf{2}$ \\
\hline Total lipids & -0.96 & 0.05 \\
TAG & -0.88 & 0.01 \\
Total cholesterol & -0.86 & 0.07 \\
HDL-cholesterol & -0.63 & 0.40 \\
LDL-cholesterol & -0.70 & -0.48 \\
VLDL-cholesterol & -0.88 & 0.01 \\
Glucose & 0.24 & -0.05 \\
Urea & 0.26 & -0.76 \\
Creatinine & 0.31 & 0.51 \\
Total protein & -0.51 & -0.26 \\
ALT & -0.31 & -0.29 \\
AST & -0.19 & -0.67 \\
ALP & -0.17 & 0.82 \\
GGT & 0.39 & -0.28 \\
\hline TAG tiacylycerosi
\end{tabular}

TAG - triacylglycerols; HDL - high-density lipoproteins; LDL - low-density lipoproteins; VLDL - very low-density lipoproteins; ALT - alanine aminotransferase (EC 2.6.1.2); AST - aspartate aminotransferase (E.C. 2.6.1.1); ALP - alkaline phosphatase (EC 3.1.3.1); GGT - gamma-glutamyltransferase (EC 2.3.2.13) in different quadrants (Fig. 1B). The control group was set well aggregated in quadrant $b$ and $\mathrm{CH}$ group in quadrant $d$. The other groups fed microalga-based diets supplemented with exogenous CAZymes, were located more dispersed in quadrants $c(\mathrm{CHR})$ and $a(\mathrm{CHM})$.

\section{Discussion}

In the present study, the dietary incorporation of $(10 \%$ C. vulgaris, supplemented or not with the two feed CAZyme mixtures, Rovabio and the four-CAZyme mixture described by Coelho et al. [17], has no significant effects on productive parameters and, therefore, does not compromise growth performance of broilers. These findings partially agree with the literature because, so far, most of the studies in poultry nutrition are focused in the use of $C$. vulgaris as supplement ( $<2 \%$ in diet) [2, 23]. Previous reports observed that low incorporation levels $(0.07-1.25 \%)$ of Chlorella in broilers promotes a decrease of FCR with no influence in ADG [24, 25]]. Similarly, Dlouha et al. [26] and Kang et al. [27] described a positive effect on ADG without changes on feed/gain ratio and FCR with supplementation of Chlorella sp. in broiler chicken diets during 42 and 28 days, respectively. Thus, it seems that the level of $C$. vulgaris inclusion in the diet and the duration of the experimental trial impact broilers performance. Herein, the supplementation of $10 \%$ C. vulgaris with the two exogenous CAZymes does not seem to be necessary in the response of broilers to productive parameters.

Plasma biochemical parameters are a useful tool for assessing metabolic changes in organs and tissues. Even 
though plasma lipid profile was largely affected by the dietary treatments, our results does not confirm the findings of Kotrbáček et al. [28], who reported that dietary Chlorella biomass did not affect plasma TAG and cholesterol concentrations in laying hens. Likewise, An et al. [29] found that blood parameters, including albumin, total protein, AST, total cholesterol, HDL cholesterol and triacylglycerols, were not altered by dietary treatments in broiler chickens. Lately, Abdelnour et al. [23] showed that blood total protein and HDLcholesterol of broilers can be positively affected by addition of low amounts (0.5-1.0\% of the diet) of C. vulgaris biomass to feed. Here, the concentration of total protein also increased with the incorporation of C. vulgaris at high-level (10\%) in broiler diets, individually or combined with both mixtures of exogenous CAZymes. However, the increment in cholesterol transport of LDL promoted by this microalga, and even more in association with exogenous CAZymes, was not countered by reverse cholesterol transport of $\mathrm{HDL}$, increasing the ratio total cholesterol/HDL-cholesterol. Moreover, total lipids, total cholesterol and VLDL-cholesterol were higher in broilers fed C. vulgaris supplemented with both exogenous CAZymes. Data suggest that C. vulgaris, at this high level (10\%), might enhance the intestinal absorption of dietary lipids. Thus, the present study does not corroborates the well-established cholesterol- and lipid-lowering properties of Chorella [30]. Although the mechanism of the hypocholesterolemic effect are still unclear, it seems that Chlorella enhances cholesterol catabolism through the up-regulation of hepatic cholesterol $7 \alpha$-hydroxylase expression [31]. In addition, Chlorella may inhibit the intestinal absorption of excess cholesterol from the diet and to enhance faecal steroid excretion, and thus, preventing hypercholesterolemia [32]. Animal and human trials have been shown an ameliorative effect on plasma lipid profiles [33, 34] upon supplementation of Chlorella, which can be ascribed to a decrease in intestinal tract fat absorption [35]. Zheng et al. [20] found lower TAG levels in laying hens supplemented with fermented $C$. vulgaris. The former authors hypothesised that the reason for the decreased plasma TAG concentration of laying hens was the inhibition of hepatic fatty acid synthesis and triacylglycerol production. Previous studies have shown that the nutritional composition of $C$. vulgaris may contribute to their effects on mitigating metabolic alterations through different mechanisms [36, 37]. Several algae-derived bioactive compounds, like lipids, antioxidants, pigments, vitamins and polysaccharides are known to have beneficial effects on human and animal health [38-40]. In contrast, here, data suggest that both feed carbohydrate-degrading enzymes (Rovabio and the pre-selected four-CAZyme mixture) were effective to hydrolyse $C$. vulgaris cell wall polysaccharides that changed fibre gut profile, thus reducing its anti-hyperlipidaemic activity. To date, animal studies have investigated the potential hypoglycaemic effect of Chlorella and the mechanisms by which Chlorella might exert protection against diabetes [41, 42]. In the current study, glucose was found decreased with C. vulgaris when combined with the four-CAZyme mixture, suggesting a positive effect on glycemia homeostasis. The aforementioned studies [41, 42] reported that the intake of low levels of Chlorella, in normal and induceddiabetic mice and insulin resistant rats, respectively, might lower the plasma glucose but affects the insulin secretion capacity very slightly or not at all. Therefore, further experiments are required to clarify the hypoglycaemic effect of Chlorella and to elucidate the effective doses that are responsible for the positive effect on insulin sensitivity. The antidiabetic effect of Chlorella has been linked to the action of Chlorella-derived components, including polysaccharides [43, 44]. Also, C. vulgaris has been reported to have antioxidant properties and even to aid detoxification. It is well established that hepatocytes are in the frontline against oxidative damage [45]. Even though growing evidence from animal and human studies suggests that $C$. vulgaris can be a promising hepatoprotective agent, the results are still controversial, as recently reviewed by Yarmohammadi et al. [46]. Herein, none of the aminotransferases enzymes (AST and ALT) was affected by dietary inclusion of $10 \%$ C. vulgaris, supplemented or not with both exogenous CAZymes. In contrast, Abdelnour et al. [23] reported a decrease of $23 \%$ in the levels of liver enzymes in broilers supplemented with dietary $C$. vulgaris compared to the control birds. In the present study, ALP and GGT activities changed in the opposite direction, while ALP levels increased in broilers fed microalga supplemented with the four-CAZyme mixture, the GGT levels significantly decreased. Regarding indicators of renal function, creatinine kept unchanged whereas urea reached the highest value with $C$. vulgaris incorporation. The discrepancy in response to hepatic and renal biomarkers in different trials could be partly ascribed to the dosage and source of microalga, as well as experimental period duration and conditions. Overall, plasma biochemical parameters enabled broilers to be assigned into their experimental diets with good accuracy, which are well distributed by the four quadrants, as shown by the discriminant analysis.

Liver is the hub of cholesterol synthesis and fatty acid oxidation. Moreover, de novo lipogenesis occurs essentially in both liver and adipose tissue [47]. Hepatic total lipids and total cholesterol concentrations as well as the majority of individual fatty acids identified were not affected by the incorporation of $10 \%$ C. vulgaris in diets nor by the supplementation with the exogenous 
CAZymes. However, C16:1c7 and C20:3n-3 increased about 1.7-fold and 1.5-fold, respectively, in broilers fed C. vulgaris compared with the control group. In addition, the $n-6 / n-3$ ratio showed a significant reduction, of about $18 \%$, in microalga-fed animals compared to the control group, which indicates that $\mathrm{CH}$ diet, in general, promoted an increase in the concentration of $n$ 3 PUFA in broiler liver. Our results agree with those conducted by Zheng et al. [20], who analysed the effect of dietary fermented C. vulgaris on growth performance, liver lipids and intestinal microflora of laying hens. The former authors found only a significant effect in triacylglycerols, without no differences for cholesterol and phospholipids. Later, Gatrell and colleagues [48] using different levels of incorporation of defatted green microalga Nannochloropsis oceanica biomass observed an increase of C20:5n-3 and C22:6n-3 fatty acids, as well as in the sum of $n-3$ PUFA, accompanied with a decrease of the $n-6 / n-3$ ratio in liver of broilers. It is well known that Nannochloropsis oceanica presents a superior concentration of n-3 PUFA when compared with C. vulgaris. Hence, defatted green microalga Nannochloropsis oceanica promoted more extensive variations in liver lipids than those obtained herein by dietary incorporation of C. vulgaris in broilers. Tao et al. [49] also documented an increase of $n-3$ PUFA and a decrease of the $n-6 / n-3$ ratio in liver with the inclusion of $10 \%$ of defatted $N$. oceanica biomass in chicken diet. This enrichment of liver in $n$-3 PUFA has been associated with the downregulation of PUFA oxidation-related gene expression, attenuated lipid peroxidation and enhanced antioxidant activities [49].

The influence of dietary incorporation of C. vulgaris, supplemented or not with exogenous CAZymes, on hepatic levels of vitamin $\mathrm{E}$ and pigments was also explored. $\alpha$-Tocopherol was the major vitamin $\mathrm{E}$ homologue in all groups fed with the experimental diets, while $\gamma$ tocopherol was present at lower concentrations, which strongly agrees with diet composition. Tao et al. [49] also documented no changes on hepatic $\alpha$-tocopherol levels of broilers through the incorporation of $10 \%$ defatted $N$. oceanica, probably due to similar vitamin E content in both microalgae [50,51]. C. vulgaris is also rich in pigments, such as chlorophylls and carotenoids, due to the photosynthetic pathway $[52,53]$. $\beta$-carotene content, a precursor of vitamin $\mathrm{A}$, increased about 3.7 -fold in liver of broilers fed C. vulgaris alone, whereas total carotenoids increased about 4.5-fold in all microalga groups. These results agree with previous researches, which observed a consistent increase of lutein and total carotenoids in liver of laying hens fed with conventional or lutein-enriched Chlorella [54, 55]. Although the dietary inclusion of $10 \%$ C. vulgaris did not allow an increase in hepatic vitamin $E$, the raise of $\beta$-carotene and total carotenoids contents in liver is a key indicator of its bioavailability from diets. Hence, C. vulgaris is an excellent source of antioxidant compounds, like $\alpha$ tocopherol and carotenoids, which are known to counterbalance oxidative stress and promote animal health [56].

\section{Conclusions}

Collectively, data indicate that C. vulgaris incorporated as a feed ingredient $(10 \%)$ in broiler diets improves liver composition but negatively affects systemic lipemia, without impairing, in general, animal health and growth performance. Moreover, the supplementation of diets with the exogenous CAZymes are no needed at this inclusion level of C. vulgaris. Although these results indicate the viability of $C$. vulgaris as feedstock in poultry nutrition, further experiments are required to confirm these findings under different experimental conditions, including other percentages of $C$. vulgaris incorporation in the diet, in order to determine the minimal effective dose for a positive effect on biochemical metabolites and lipid metabolism. Future work should also elucidate the molecular mechanisms involved in lipid metabolic changes.

\section{Methods}

\section{Recombinant four-CAZyme mixture production}

The pre-selected recombinant four-CAZyme mixture is composed by exo- $\beta$-glucosaminidase, alginate lyase, peptidoglycan $\mathrm{N}$-acetylmuramic acid deacetylase and lysozyme, which in a concentration of $20 \mathrm{mg} / \mathrm{L}$ exhibits $1.21 \mathrm{~g} / \mathrm{L}$ of reducing sugars released upon a $20 \mathrm{~g} / \mathrm{L}$ of $C$. vulgaris suspension as subtract [17]. The genes encoding the four recombinant CAZymes, which composed the enzyme mixture, were cloned using the procedure described by Coelho et al. [17]. Succinctly, the generated recombinant plasmids were used to transform BL21 Escherichia coli cells that were grown on Luria-Bertani media until reach the mid exponential phase (0.4-0.6 of absorbance at $\lambda=595 \mathrm{~nm}$ ). In order to induce recombinant gene expression, isopropyl $\beta$-d-thiogalactoside was added. The induction of protein expression occurred with incubation of BL21 cells overnight and, after ultrasonication of cells, centrifugation and freeze dried, the four-CAZyme protein extracts were mixed in equivalent weight amounts at a final level of $0.01 \%$.

\section{Animals, feeding protocol and sampling}

The experimental procedures were carried out at the facilities of Instituto Superior de Agronomia (ISA, Universidade de Lisboa), reviewed by the Ethics Commission of CIISA (FMV) and approved by the Animal Care Committee of the National Veterinary Authority (DGAV, Portugal), following the ARRIVE guidelines and the 
European Union legislation (2010/63/EU Directive). One hundred and twenty Ross 308 male birds were raised in 40 wired-floor cages. Each cage was $66 \times 66 \mathrm{~cm}$. All birds were kept in a thermostatically controlled room with constant light. Environmental temperature was monitored continuously, which gradually decrease from $31^{\circ} \mathrm{C}$ (day 0 ) to $21{ }^{\circ} \mathrm{C}$ (day 22) and remained constant until the end of the trial. The experimental design was performed with 10 replicate pens per treatment, with 3 birds per pen. Before the beginning of the trial, birds received a corn-based diet during 21 days. After an acclimation period, one of the four isocaloric and isonitrogenous diets were randomly allocated to each pen: (1) corn-soybean meal based diet (control); (2) based diet with $10 \%$ of $C$. vulgaris supplied by Allmicroalgae (Natural Products, Portugal) $(\mathrm{CH})$; (3) diet 2 with $10 \%$ of C. vulgaris supplemented with $0.005 \%$ of the commercial CAZyme cocktail Rovabio Excel AP from Adisseo (Antony, France), containing predominantly endo-1,4- $\beta$-xylanase 22,000 viscosity unit/g and endo-1,3(4)- $\beta$-glucanase 30,000 viscosity unit/g (CHR); and (4) diet 2 with $10 \%$ of $C$. vulgaris supplemented with $0.01 \%$ of a pre-selected four-CAZyme mixture, containing exo- $\beta$-glucosaminidase, alginate lyase, peptidoglycan $\mathrm{N}$-acetylmuramic acid deacetylase and lysozyme, as mentioned above (CHM). The experimental period lasted from day 21 to day 35. Table 6 shows the ingredients of the experimental diets. During the experiment,

Table 6 Ingredients and additives of the experimental diets (\% as fed basis)

\begin{tabular}{lllll}
\hline \multicolumn{4}{l}{ Experimental diets } \\
\hline Ingredients & Control & CH & CHR & CHM \\
Corn & 56.0 & 55.5 & 55.5 & 55.5 \\
Soybean meal & 37.0 & 26.5 & 26.5 & 26.5 \\
Soybean oil & 3.60 & 4.14 & 4.14 & 4.14 \\
Sodium chloride & 0.330 & 0.330 & 0.330 & 0.330 \\
Calcium carbonate & 1.06 & 1.00 & 1.00 & 1.00 \\
Dicalcium phosphate & 1.44 & 1.50 & 1.50 & 1.50 \\
DL-Methionine & 0.280 & 0.360 & 0.360 & 0.360 \\
L-Lysine & 0.000 & 0.370 & 0.370 & 0.370 \\
Vitamin-mineral premix & 0.300 & 0.300 & 0.300 & 0.300 \\
Chlorella vulgaris powder & - & 10.0 & 10.0 & 10.0 \\
Rovabio ${ }^{\circledR}$ Excel AP & - & - & 0.005 & - \\
Mix of 4 CAZymes & - & - & - & 0.010 \\
\hline
\end{tabular}

The broilers were fed: (1) a corn-soybean based diet (Control); (2) the based diet plus $10 \%$ C. vulgaris (CH); (3) diet 2 supplemented with $0.005 \%$ Rovabio Excel AP; and (4) diet 2 supplemented with $0.01 \%$ of a pre-selected fourCAZyme mixture (CHM)

${ }^{1}$ Premix provided the following nutrients per $\mathrm{kg}$ of diet: pantothenic acid $10 \mathrm{mg}$, vitamin $\mathrm{D}_{3} 2400 \mathrm{IU}$, cyanocobalamin $0.02 \mathrm{mg}$, folic acid $1 \mathrm{mg}$, vitamin $\mathrm{K}_{3} 2 \mathrm{mg}$, nicotinic acid $25 \mathrm{mg}$; vitamin $\mathrm{B}_{6} 2 \mathrm{mg}$, vitamin $\mathrm{A} 10,000 \mathrm{UI}$, vitamin $B_{1} 2 \mathrm{mg}$, vitamin E $30 \mathrm{mg}$, vitamin $\mathrm{B}_{2} 4 \mathrm{mg}$, Cu $8 \mathrm{mg}$, Fe $50 \mathrm{mg}, \mathrm{l} 0.7 \mathrm{mg}, \mathrm{Mn}$ $60 \mathrm{mg}$, Se $0.18 \mathrm{mg}, \mathrm{Zn} 40 \mathrm{mg}$ feed was provided daily and birds were weighed weekly. ADFI, ADG and FCR were determined for animal performance evaluation. After 35 days of trial, one bird per experimental unit was euthanised using electrical stunning followed by exsanguination, according to commercial abattoirs standard procedures. Blood samples were collected from the jugular vein and centrifuged at $1500 \mathrm{~g}$ for 15 min to obtain plasma. Liver samples were vacuum packed and stored at $-20^{\circ} \mathrm{C}$, until total lipids, total cholesterol, fatty acid composition, pigments and diterpene profile analyses.

\section{C. vulgaris and experimental diets analyses}

The proximate composition of $C$. vulgaris and experimental diets was analysed according to AOAC [57] methods. Dry matter (DM) was calculated from samples dried at $103{ }^{\circ} \mathrm{C}$ until constant weight. Crude protein of microalga and diets was determined by the Kjeldahl method using the nitrogen $(\mathrm{N})$ content and the factor 6.25. The ash content and crude fat of samples were determined through the AOAC method 942.05 [57] and by automatic Soxhlet extraction with petroleum ether (Gerhardt Analytical Systems, Königswinter, Germany), respectively. Gross energy was determined by the complete combustion of samples in an adiabatic bomb calorimeter (Parr 1261, Parr Instrument Company, Moline, IL, USA).

Fatty acid methyl esters (FAME) composition of $C$. vulgaris and experimental diets was analysed by gas chromatography, after extraction and acid transesterification, using heneicosaenoic acid (C21:0) methyl ester as the internal standard. The diterpene profile of samples was determined by HPLC according to Prates et al. [58]. The quantification of pigments in samples was performed as described by Teimouri et al. [59], with slight modifications of Pestana et al. [60] using the equations of Hynstova et al. [61]. Table 7 presents the chemical composition of $C$. vulgaris and the experimental diets.

\section{Plasma biochemical assays}

Biochemical analyses of the collected plasma were performed to determine lipid profile, glucose, urea, creatinine, total protein and liver function markers. The determination of glucose concentrations, triacylglycerols (TAG), urea, creatinine, total cholesterol, HDLcholesterol, LDL-cholesterol and total protein, alanine aminotransferase (ALT, EC 2.6.1.2), aspartate aminotransferase (AST, EC 2.6.1.1), alkaline phosphatase (ALP, EC 3.1.3.1) and gamma-glutamyltransferase (GGT, EC 2.3.2.13) were performed in a Modular Hitachi Analytical System (Roche Diagnostics, Mannheim, Germany), through diagnostic kits (Roche Diagnostics). VLDLcholesterol and total lipids were calculated by Friedewald et al. [22] and Covaci et al. [21] formulas, respectively. 
Table 7 Chemical composition of Chlorella vulgaris and experimental diets

\begin{tabular}{llllll}
\hline & Microalga & Experimental Diets & & \\
\hline Item & C. vulgaris & Control & CH & CHR & CHM \\
Energy, kcal ME/kg as fed basis & 4586 & 4614 & 4627 & 4650 & 4615 \\
Proximate composition, \% as fed basis & & & & & \\
Dry matter & 93.1 & 89.0 & 89.6 & 29.3 & 86.4 \\
Crude protein & 42.8 & 19.9 & 20.4 & 19.8 & 19.1 \\
Crude fat & 8.73 & 6.59 & 7.56 & 7.63 & 7.41 \\
Ash & 11.8 & 5.60 & 6.08 & 6.21 & 6.13
\end{tabular}

Estimated available limiting amino acid composition, $\%$ as fed basis

$\begin{array}{ll}\text { Arginine } & 3.89 \\ \text { Histidine } & 0.65 \\ \text { Isoleucine } & 1.26 \\ \text { Leucine } & 2.45 \\ \text { Lysine } & 2.63 \\ \text { Methionine } & 0.45 \\ \text { Phenylalanine } & 1.49 \\ \text { Threonine } & 2.32 \\ \text { Tryptophan } & 0.47 \\ \text { Valine } & 3.52\end{array}$

$3.89-1.42=1.08$

$1.08 \quad 1.08$

$\begin{array}{lll}0.65 & 0.55 & 0.43\end{array}$

$0.43 \quad 0.43$

$\begin{array}{lll}1.26 & 1.04 & 0.78\end{array}$

0.78

Fatty acid profile, \% total fatty acids

$\begin{array}{ll}\text { C14:0 } & 1.10 \\ \text { C16:0 } & 17.2 \\ \text { C16:1c9 } & 3.90 \\ \text { C18:0 } & 3.00 \\ \text { C18:1c9 } & 1.7 \\ \text { C18:1c11 } & 0.00 \\ \text { C18:2n-6 } & 11.2 \\ \text { C18:3n-3 } & 10.1 \\ \text { C20:0 } & 0.20 \\ \text { C20:1C11 } & 0.10\end{array}$

1.10

Diterpene profile, $\mu g / g$

$a$-Tocopherol
$\alpha$-Tocotrienol
$\beta$-Tocopherol
$\psi$-Tocopherol $+\beta$-tocotrienol
$\psi$-Tocotrienol
$\delta$-Tocopherol

Pigments, $\mu \mathrm{g} / \mathrm{g}$

$\beta$-Carotene

Chlorophyll $a^{1}$

Chlorophyll $b^{2}$

Total carotenoids ${ }^{4}$

1305

n.d. $\quad 83.6$

37.3

45.1

$0.67 \quad 307$

200

$0.90 \quad 96.3$

339

40.0

1.57

404

240

102

47.7

Total chlorophylls + Carotenoids $^{5}$

1305

505

288

The broilers were fed: (1) a corn-soybean based diet (Control); (2) the based diet plus $10 \%$ C. vulgaris (CH); (3) diet 2 supplemented with $0.005 \%$ Rovabio Excel AP; and (4) diet 2 supplemented with $0.01 \%$ of a pre-selected four-CAZyme mixture (CHM)

$\mathrm{DM}$ - dry matter; ME - metabolized energy; n.d. - not detected

${ }^{+}$Co-eluted with a-tocopherol

${ }^{1} \mathrm{Ca}=11.24 \times \mathrm{A}_{662}-2.04 \times \mathrm{A}_{645}$

${ }^{2} \mathrm{Cb}=0.13 \times \mathrm{A}_{645}-4.19 \times \mathrm{A}_{662}$

${ }^{3} \mathrm{Ca}+\mathrm{b}=7.05 \times \mathrm{A}_{662}+18.09 \times \mathrm{A}_{645}$

${ }^{4} \mathrm{Cx}+\mathrm{C}=\left(1000 \times \mathrm{A}_{470}-1.90 \times \mathrm{Ca}-63.14 \times \mathrm{Cb}\right) / 214$

${ }^{5}(\mathrm{Ca}+\mathrm{b})+(\mathrm{Cx}+\mathrm{c})$ 


\section{Analysis of total cholesterol and diterpenes in liver} The determination of total cholesterol, $\beta$-carotene and vitamin $\mathrm{E}$ homologues in liver samples was done using the protocol of Prates et al. [58]. After saponification and extraction with $n$-hexane, liver samples, in duplicate, were analysed by HPLC (Agilent 1100 Series, Agilent Technologies Inc., Palo Alto, CA, USA). Total cholesterol and $\beta$-carotene were detected by UV-Vis detection $(\lambda=202 \mathrm{~nm}$ and $\lambda=450 \mathrm{~nm}$, respectively) while tocopherols and tocotrienols by fluorescence (excitation $\lambda=295$ $\mathrm{nm}$ and emission $\lambda=325 \mathrm{~nm}$ ). Quantification of total cholesterol and diterpenes in liver samples was performed using standard curves of peak area versus concentration.

\section{Analysis of pigments in liver}

The determination of pigments was carried out as mentioned above for experimental diets, according to Teimouri et al. [59] with slight modifications by Pestana et al. [60]. The simultaneous extraction of pigments was performed by incubation of liver samples with acetone overnight (Merck KGaA, 249 Darmstadt, Germany). Then, samples were centrifuged and the absorbance of the supernatants were measured by UV-Vis spectrophotometry (Ultrospec 3100 pro, Amersham Biosciences, Little Chalfont, UK). The amount of pigments in liver samples was calculated as described by Hynstova et al. [61].

\section{Analysis of total lipids and fatty acid composition in liver}

Total lipids were determined, in duplicate, gravimetrically from lyophilised $\left(-60{ }^{\circ} \mathrm{C}\right.$ and $2.0 \mathrm{hPa}$, lyophilizator Edwards Modulyo, Crawley, UK) liver samples according to Folch et al. [62]. Fatty acids were converted to FAME by sequential alkaline and acid transesterification and analysed by gas chromatography (HP7890A HewlettPackard, Avondale, PA) as described in Alfaia et al. [63]. Identification of FAME was based on the reference standard FAME mix 37 components (Supelco Inc.), which was confirmed by gas chromatography coupled with mass spectrometry using a GC-MS QP2010-Plus (Shimadzu, Kyoto, Japan). Heneicosanoic acid (C21:0) methyl ester was the internal standard used for the quantification of FAME. The fatty acids identified were expressed as the percentage of total fatty acids.

\section{Data analysis}

The normal distribution and variance homogeneity were checked for all data using Shapiro-Wilk test and Levene's test, respectively. Data were analysed by ANOVA using the PROC GLM of SAS software package (version 9.4; SAS Institute Inc., Cary, NC, USA). The dietary treatment (Control, $\mathrm{CH}, \mathrm{CHR}$ and $\mathrm{CHM}$ ) was the only source of variation (fixed effect). For feed intake and feed conversion ratio parameters, cage within each treatment was the experimental unit, whereas for blood and hepatic measurements, bird within each treatment was the experimental unit. Statistical differences among experimental diets were evaluated by least square means generated using the PDIFF option adjusted with TukeyKramer. The significance level was set at $p<0.05$. In addition, a principal component analysis (PCA) was performed with the parameters measured in plasma and liver samples using the Statistica program (version 8.0; TIBCO software, Palo Alto, CA, USA).

\section{Abbreviations}

ADFI: average daily feed intake; ADG: average daily gain; ALT: alanine aminotransferase; ALP: alkaline phosphatase; AST: aspartate aminotransferase; CAZymes: carbohydrate-active enzymes; $\mathrm{CH}$ : Chlorella vulgaris; FAME: fatty acid methyl esters; FCR: feed conversion ratio; GGT: gammaglutamyltransferase; HDL: high-density lipoprotein cholesterol; LDL: lowdensity lipoprotein cholesterol; MUFA: monounsaturated fatty acids; PCA: principal component analysis; PUFA: polyunsaturated fatty acids; SFA: saturated fatty acids; TAG: triacylglycerols; VLDL: very-low-density lipoprotein cholesterol

\section{Supplementary information}

The online version contains supplementary material available at https://doi. org/10.1186/s12917-021-02932-8.

Additional file 1 Supplementary Figure 1. Loading plot of the first and second principal components of the pooled data $(\mathbf{A})$ and component score vectors (B) using hepatic parameters analysed from broilers fed Chlorella vulgaris, individually and combined with exogenous CAZymes. Dietary treatments: corn-soybean meal based diet (control); based diet with $10 \%$ of $\mathrm{C}$. vulgaris $(\mathrm{CH})$; based diet with $10 \%$ of $\mathrm{C}$. vulgaris supplemented with $0.005 \%$ Rovabio ${ }^{\circledR}$ Excel AP (CHR); based diet with $10 \%$ of C. vulgaris supplemented with $0.01 \%$ of a pre-selected fourCAZyme mixture (CHM).

\section{Acknowledgements}

The authors thank Eng. Teresa Costa (Indukern, Lda., Sintra, Portugal) for offering the Rovabio ${ }^{\circ}$ Excel AP used in this study, and Rita Jorge, BA, PGD Educational Leadership, State Examinations Setter, Cambridge qualified English teacher.

\section{Authors' contributions}

Conceptualization, M.M.L. and J.A.M.P.; Methodology, D.C., J.P., M.C., C.M.A., R.P. and C.M.G.A.F.; writing-draft preparation, D.C. and C.M.A.; writing-review and editing, J.A.M.P.; project administration, J.A.M.P.; funding acquisition, J.A.M.P. All authors have read and agreed to the published version of the manuscript. The author(s) read and approved the final manuscript.

\section{Funding}

This work was funding by Fundação para a Ciência e a Tecnologia (FCT, Lisboa, Portugal) grant (PTDC/CVT-NUT/5931/2014), Portugal2020 grant (08/ SI/3399/2015) and CIISA (Project UIDB/00276/2020). Author D.C. acknowledge a PhD fellowship (SFRH/BD/126198/2016) and author J.P. (SFRH/BPD/116816/ 2016) acknowledge a Postdoctoral fellowship, all from FCT. The funders were not involved in the design of the study and collection, analysis, and interpretation of data and in writing the manuscript.

\section{Availability of data and materials}

All data generated during this study are included in this published article. The datasets generated during the current study are available from the corresponding author on demand. 


\section{Declarations}

\section{Ethics approval and consent to participate}

Animal trial was conducted at the facilities of Instituto Superior de Agronomia (ISA), Universidade de Lisboa. All the procedures were reviewed by the Ethics Commission of CIISA/FMV and approved by the Animal Care Committee of the National Veterinary Authority (Direção Geral de Alimentação e Veterinária, Portugal), following the guidelines of the European Union legislation (2010/63/EU Directive).

\section{Consent for publication}

Not applicable.

\section{Competing interest}

All authors declare that there are no competing interests.

\section{Author details}

'CIISA - Centro de Investigação Interdisciplinar em Sanidade Animal, Faculdade de Medicina Veterinária, Universidade de Lisboa, 1300-477 Lisboa, Portugal. ${ }^{2}$ iMed.UL, Faculdade de Farmácia, Universidade de Lisboa, Avenida Professor Gama Pinto, 1649-003 Lisboa, Portugal. ${ }^{3}$ LEAF - Linking Landscape, Environment, Agriculture And Food, Instituto Superior de Agronomia, Universidade de Lisboa, Tapada da Ajuda, 1349-017 Lisboa, Portugal.

Received: 14 March 2021 Accepted: 7 June 2021

Published online: 29 June 2021

\section{References}

1. Guaragni A, Boiago MM, Bottari NB, Morsch VM, Lopes TF, da Silva AS. Feed supplementation with inulin on broiler performance and meat quality challenged with Clostridium perfringens: Infection and prebiotic impacts. Microb Pathog. 2020;139:103889.

2. Madeira MS, Cardoso C, Lopes PA, Coelho D, Afonso C, Bandarra NM, Prates JAM. Microalgae as feed ingredients for livestock production and meat quality: a review. Livest Sci. 2017;205:111-21.

3. Camacho F, Macedo A, Malcata, F. Potential industrial applications and commercialization of microalgae in the functional food and feed industries: a short review. Mar Drugs. 2019;17:312.

4. Lum KK, Kim J, Lei XG. Dual potential of microalgae as a sustainable biofuel feedstock and animal feed. J Anim Sci Biotechnol. 2013;4:53.

5. Ryckebosch E, Bruneel C, Muylaert K, Foubert I. Microalgae as an alternative source of omega-3 long chain polyunsaturated fatty acids. Lipid Technol. 2012;24:128-30.

6. Draaisma RB, Wijffels RH, Slegers PE, Brentner LB, Roy A, Barbosa MJ. Food commodities from microalgae. Curr Opin Biotechnol. 2013;24:169-77.

7. Liu J, Chen F. Biology and Industrial Applications of Chlorella: Advances and Prospects. In: Posten C, Feng Chen S, editors. Microalgae Biotechnology. Advances in Biochemical Engineering/Biotechnology. Springer, Cham; 2014. p. 1-35.

8. Kotrbáček V, Doubek J, Doucha J. The chlorococcalean alga Chlorella in animal nutrition: a review. J Appl Phycol. 2015;27:2173-80.

9. Acton Q. Cellular structures. In: Acton QA, editor. Advances in Research and Application. Scholarly Editions; 2013. p. 946.

10. Baudelet PH, Ricochon G, Linder M, Muniglia L. A new insight into cell walls of Chlorophyta. Algal Res. 2017;25:333-71.

11. Teuling E, Wierenga PA, Agboola JO, Gruppen H, Schrama JW. Cell wall disruption increases bioavailability of Nannochloropsis gaditana nutrients for juvenile Nile tilapia (Oreochromis niloticus). Aquaculture. 2019;499:269-82.

12. Ravindran V, Son JH. Feed enzyme technology: present status and future developments. Recent Pat Food Nutr Agric. 2011;3:102-9.

13. Garron ML, Henrissat B. The continuing expansion of CAZymes and their families. Curr Opin Chem Biol. 2019;5:82-87.

14. Hashemi M, Seidavi A, Javandel F, Gamboa S. Influence of non-starch polysaccharide-degrading enzymes on growth performance, blood parameters, and carcass quality of broilers fed corn or wheat/barley-based diets. Rev Colom Cienc Pecua. 2017;30:286-98

15. Cho HS, Oh YK, Park SC, Lee JW, Park JY. Effects of enzymatic hydrolysis on lipid extraction from Chlorella vulgaris. Renew Energy. 2013;54:156-60.

16. Phong WN, Show PL, Ling TC, Juan JC, Ng EP, Chang JS. Mild cell disruption methods for bio-functional proteins recovery from microalgae - recent developments and future perspectives. Algal Res. 2018;31:506-16.
17. Coelho D, Lopes PA, Cardoso V, Ponte P, Brás J, Madeira MS, Alfaia CM, Bandarra NM, Gerken, HG, Fontes CMGA, Prates JAM. Novel combination of feed enzymes to improve the degradation of Chlorella vulgaris recalcitrant cell wall. Sci Rep. 2019;9:1-11.

18. Panahi Y, Darvishi B, Jowzi N, Beiraghdar F, Sahebkar A. Chlorella vulgaris: a multifunctional dietary supplement with diverse medicinal properties. Curr Pharm Des. 2016;22:164-73.

19. Fallah AA, Sarmast E, Habibian Dehkordi S, Engardeh J, Mahmoodnia L, Khaledifar A, Jafari T. Effect of Chlorella supplementation on cardiovascular risk factors: a meta-analysis of randomized controlled trials. Clin Nutr. 2018; 37:1892-901.

20. Zheng L, Oh ST, Jeon JY, Moon BH, Kwon HS, Lim SU, An BK, Kang CW. The dietary effects of fermented Chlorella vulgaris $\left(\mathrm{CBT}^{\oplus}\right)$ on production performance, liver lipids and intestinal microflora in laying hens. AsianAustralas J Anim Sci. 2012:25:261.

21. Covaci A, Voorspoels S, Thomsen C, van Bavel B, Neels H. Evaluation of total lipids using enzymatic methods for the normalization of persistent organic pollutant levels in serum. Sci Total Environ. 2006;366:361-66.

22. Friedewald WT, Levy RI, Fredrickson DS. Estimation of the concentration of low-density lipoprotein cholesterol in plasma, without use of the preparative ultracentrifuge. Clin Chem. 1972;18:499-502.

23. Abdelnour SA, Abd El-Hack ME, Arif M, Khafaga AF, Taha AE. The application of the microalgae Chlorella spp. as a supplement in broiler feed. Worlds Poult Sci J. 2019;75:305-18.

24. Rezvani M, Zaghari M, Moravej H. A survey on Chlorella vulgaris effect's on performance and cellular immunity in broilers. International J Agric Sci Res. 2012:3:9-15.

25. Englmaierová M, Skrivan M, Bubancová I. A comparison of lutein, spraydried Chlorella, and synthetic carotenoids effects on yolk colour, oxidative stability, and reproductive performance of laying hens. Czech J Anim Sci. 2013;58:412-9.

26. Dlouha G, Sevcikova S, Dokoupilova A, Zita L, Heindl J, Skrivan M. Effect of dietary selenium sources on growth performance, breast muscle selenium, glutathione peroxidase activity and oxidative stability in broilers. Czech J Anim Sci. 2008;53:265.

27. Kang HK, Salim HM, Akter N, Kim DW, Kim JH, Bang HT, Kim MJ, Na JC, Hwangbo J, Choi HC, Suh OS. Effect of various forms of dietary Chlorella supplementation on growth performance, immune characteristics, and intestinal microflora population of broiler chickens. J Appl Poult Res. 2013; 22:100-8.

28. Kotrbáček V, Skrivan M, Kopecky J, Penkava O, Hudečková P, Uhríková I, Doubek J. Retention of carotenoids in egg yolks of laying hens supplemented with heterotrophic CLV. Czech J Anim Sci. 2013;58:193-200.

29. An BK, Kim KE, Jeon JY, Lee KW. Effect of dried CLV vulgaris and CLV growth factor on growth performance, meat qualities and humoral immune responses in broiler chickens. Springer Plus. 2016;5:718.

30. Cherng JY, Shih MF. Preventing dyslipidemia by Chlorella pyrenoidosa in rats and hamsters after chronic high fat diet treatment. Life Sci. 2005a;76:3001-13.

31. Shibata S, Hayakawa K, Egashira Y, Sanada H. Hypocholesterolemic mechanism of Chlorella: Chlorella and its indigestible fraction enhance hepatic cholesterol catabolism through up-regulation of cholesterol 7ahydroxylase in rats. Biosci Biotechnol Biochem. 2007;71:916-25.

32. Lee HS, Park HJ, Kim MK. Effect of Chlorella vulgaris on lipid metabolism in Wistar rats fed high fat diet. Nutr Res Pract. 2008;2:204-10.

33. Shibata S, Oda K, Onodera-Masuoka N, Matsubara S, Kikuchi-Hayakawa H, Ishikawa F, Iwabuchi A, Sansawa H. Hypocholesterolemic effect of indigestible fraction of Chlorella regularis in cholesterol-fed rats. J Nutr Sci Vitaminol. 2001;47:373-7.

34. Ryu NH, Lim Y, Park JE, Kim J, Kim JY, Kwon SW, Kwon O. Impact of daily Chlorella consumption on serum lipid and carotenoid profiles in mildly hypercholesterolemic adults: a double-blinded, randomized, placebocontrolled study. Nutr J. 2014;13:57.

35. Sano T, Kumamoto Y, Kamiya N, Okuda M, Tanaka Y. Effect of lipophilic extract on Chlorella vulgaris on alimentary hyperlipidemia in cholesterol-fed rats. Artery. 1988; 15:217-224.

36. de Jesus Raposo MF, de Morais AMMB., de Morais RMSC. Marine polysaccharides from algae with potential biomedical applications. A review. Mar Drugs. 2015;13:2967-3028.

37. Ramos-Romero S, Torrella JR, Pagès T, Viscor G, Torres JL. Edible microalgae and their bioactive compounds in the prevention and treatment of metabolic alterations. Nutrients. 2021;13:563. 
38. Bito T, Okumura E, Fujishima M, Watanabe F. Potential of Chlorella as a dietary supplement to promote human health. Nutrients 2020;12:2524.

39. Barkia I, Saari N, Manning SR. Microalgae for high-value products towards human health and nutrition. Mar Drugs. 2019;17:304

40. Liu WC, Guo Y, Zhihui Z, Jha R, Balasubramanian B. Algae-derived polysaccharides promote growth performance by improving antioxidant capacity and intestinal barrier function in broiler chickens. Front Vet Sci. 2020;7:990.

41. Cherng JY, Shih MF. Potential hypoglycemic effects of Chlorella in streptozotocin-induced diabetic mice. Life Sci. 2005b; 77:980-90.

42. Jeong H, Kwon HJ, Kim MK. Hypoglycemic effect of Chlorella vulgaris intake in type 2 diabetic Goto-Kakizaki and normal Wistar rats. Nutr Res Pract. 2009; 3:23-30.

43. Tsai JS, Liu PY, Pan Sun B. A composition for reducing insulin resistance. Patent TWI487529B, 11 June 2015. p. 1-41.

44. Wang P, Cui J. Preparing Chlorella polysaccharides for preventing and treating diabetes, and its application. Patent CH108164613A, 22 January 2018.

45. Jadeja RN, Devkar RV, Nammi S. Oxidative stress in liver diseases: pathogenesis, prevention, and therapeutics. Oxid Med Cell Longev. 2017; 8341286.

46. Yarmohammadi S, Hosseini-Ghatar R, Foshati S, Moradi M, Hemati N, Moradi S, Kermani MAJ, Farzaei MH, Khan $\mathrm{H}$. Effect of Chlorella vulgaris on liver function biomarkers: a systematic review and meta-analysis. Clin Nutr Res. 2021;10:83-94.

47. Nafikov RA, Beitz DC. Carbohydrate and lipid metabolism in farm animals. J Nutr. 2007;137:702-5.

48. Gatrell SK, Kim J, Derksen TJ, O'Neil EV, Lei XG. Creating $\omega$-3 fatty-acidenriched chicken using defatted green microalgal biomass. J Agric Food Chem. 2015:63:9315-22.

49. Tao L, Sun T, Magnuson AD, Qamar TR, Lei XG. Defatted microalgaemediated enrichment of $n-3$ polyunsaturated fatty acids in chicken muscle is not affected by dietary selenium, vitamin E, or corn oil. J Nutr. 2018;148: 1547-55.

50. Andrade LM, Andrade C, Dias M, Nascimento C, Mendes M. Chlorella and Spirulina microalgae as sources of functional foods, nutraceuticals, and food supplements; an overview. MOJ Food Process Technol. 2018;6:00144.

51. Zanella L, Vianello F. Microalgae of the genus Nannochloropsis: chemical composition and functional implications for human nutrition. J Funct Foods. 2020;68:103919.

52. Batista AP, Gouveia L, Bandarra NM, Franco JM, Raymundo A (2013). Comparison of microalgal biomass profiles as novel functional ingredient for food products. Algal Res. 2013;2:164 - 73.

53. Świątkiewicz S, Arczewska-Włosek A, Józefiak D. Application of microalgae biomass in poultry nutrition. Worlds Poult Sci J. 2015;71:663-72.

54. Leeson S, Caston L, Namkung AH. Effect of dietary lutein and flax on performance, egg composition and liver status of laying hens. Can J Anim Sci. 2007:87:365-72.

55. An BK, Jeon JY, Kang CW, Kim JM, Hwang JK. The tissue distribution of lutein in laying hens fed lutein fortified Chlorella and production of chicken eggs enriched with lutein. Korean J Food Sci Anim Resour. 2014;34:172

56. Nabi F, Arain MA, Rajput N, Alagawany M, Soomro J, Umer M, Soomro F, Wang Z, Ye R, Liu J. Health benefits of carotenoids and potential application in poultry industry: a review. J Anim Physiol Anim Nutr. 2020; 104:1809-18.

57. AOAC. 2000. Official methods of analysis. Assoc. Offic. Anal. Chem. 17th ed. Arlington, VA, USA. AOAC. Official methods of analysis. 17th ed. Arlington: Assoc Offic Anal Chem. 2000

58. Prates JAM, Quaresma MAG, Bessa RJB, Fontes CMGA, Alfaia CMPM. Simultaneous HPLC quantification of total cholesterol, tocopherols and [beta]-carotene in Barrosã-PDO veal. Food Chem. 2006;94:469-77.

59. Teimouri M, Amirkolaie AK, Yeganeh S. The effects of Spirulina platensis meal as feed supplement on growth performance and pigmentation of rainbow trout (Oncorhynchus mykiss). Aquaculture. 2013;396:14-9.

60. Pestana JM, Puerta B, Santos H, Madeira MS, Alfaia CM, Lopes PA, Pinto RMA, Lemos JPC, Fontes CMGA, Lordelo MM, Prates JAM. Impact of dietary incorporation of Spirulina (Arthrospira platensis) and exogenous enzymes on broiler performance, carcass traits, and meat quality. Poult Sci. 2020;99: 2519-32.
61. Hynstova V, Sterbova D, Klejdus B, Hedbavny J, Huska D, Adam V. Separation, identification and quantification of carotenoids and chlorophylls in dietary supplements containing Chlorella vulgaris and Spirulina platensis using high performance thin layer chromatography. J Pharm Biomed Anal. 2018;148:108-18.

62. Folch J, Lees M, Stanley GHS. A simple method for the isolation and purification of total lipids from animal tissues. J Biol Chem. 1957;226:497-509.

63. Alfaia CM, Pestana JM, Rodrigues M, Coelho D, Aires MJ, Ribeiro DM, Major VT, Martins CF, Santos H, Lopes PA, Lemos JPC, Fontes CMGA, Lordelo MM, Prates JAM. Influence of dietary Chlorella vulgaris and carbohydrate-active enzymes on growth performance, meat quality and lipid composition of broiler chickens. Poult Sci. 2021;100:926-37.

\section{Publisher's Note}

Springer Nature remains neutral with regard to jurisdictional claims in published maps and institutional affiliations.
Ready to submit your research? Choose BMC and benefit from:

- fast, convenient online submission

- thorough peer review by experienced researchers in your field

- rapid publication on acceptance

- support for research data, including large and complex data types

- gold Open Access which fosters wider collaboration and increased citations

- maximum visibility for your research: over $100 \mathrm{M}$ website views per year

At BMC, research is always in progress.

Learn more biomedcentral.com/submissions 